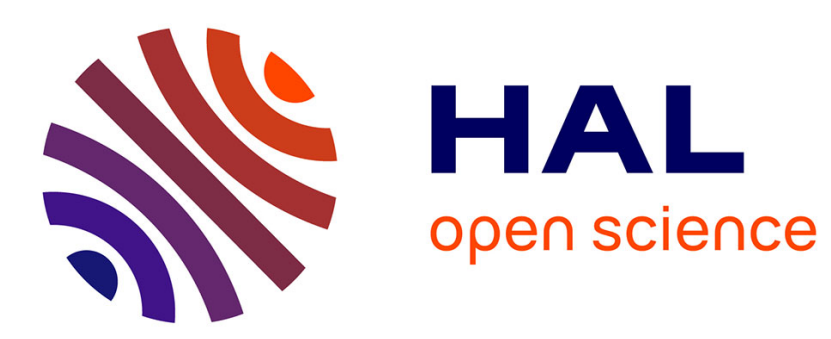

\title{
Signaling to Heme Oxygenase-1 and its Anti-Inflammatory Therapeutic Potential
}

Ananta Paine, Britta Eiz-Vesper, Rainer Blasczyk, Stephan Immenschuh

\section{To cite this version:}

Ananta Paine, Britta Eiz-Vesper, Rainer Blasczyk, Stephan Immenschuh. Signaling to Heme Oxygenase-1 and its Anti-Inflammatory Therapeutic Potential. Biochemical Pharmacology, 2010, 80 (12), pp.1895. 10.1016/j.bcp.2010.07.014 . hal-00637151

\section{HAL Id: hal-00637151 https://hal.science/hal-00637151}

Submitted on 31 Oct 2011

HAL is a multi-disciplinary open access archive for the deposit and dissemination of scientific research documents, whether they are published or not. The documents may come from teaching and research institutions in France or abroad, or from public or private research centers.
L'archive ouverte pluridisciplinaire HAL, est destinée au dépôt et à la diffusion de documents scientifiques de niveau recherche, publiés ou non, émanant des établissements d'enseignement et de recherche français ou étrangers, des laboratoires publics ou privés. 


\section{Accepted Manuscript}

Title: Signaling to Heme Oxygenase-1 and its Anti-Inflammatory Therapeutic Potential

Authors: Ananta Paine, Britta Eiz-Vesper, Rainer Blasczyk, Stephan Immenschuh

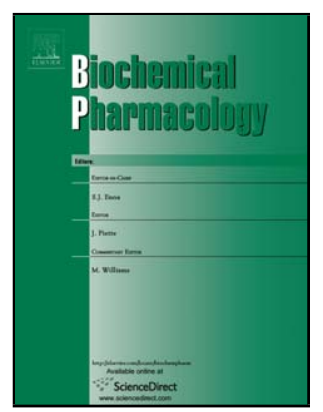

PII:

S0006-2952(10)00525-3

DOI: doi:10.1016/j.bcp.2010.07.014

Reference: BCP 10647

To appear in: $\quad B C P$

Received date: $\quad$ 5-5-2010

Revised date: $\quad$ 5-7-2010

Accepted date: $\quad 8-7-2010$

Please cite this article as: Paine A, Eiz-Vesper B, Blasczyk R, Immenschuh S, Signaling to Heme Oxygenase-1 and its Anti-Inflammatory Therapeutic Potential, Biochemical Pharmacology (2010), doi:10.1016/j.bcp.2010.07.014

This is a PDF file of an unedited manuscript that has been accepted for publication. As a service to our customers we are providing this early version of the manuscript. The manuscript will undergo copyediting, typesetting, and review of the resulting proof before it is published in its final form. Please note that during the production process errors may be discovered which could affect the content, and all legal disclaimers that apply to the journal pertain. 


\section{REVIEW}

\section{Signaling to Heme Oxygenase-1 and its Anti-Inflammatory}

\section{Therapeutic Potential*}

Ananta Paine, Britta Eiz-Vesper, Rainer Blasczyk, Stephan Immenschuh

Institute for Transfusion Medicine, Hannover Medical School, Hannover, Germany

${ }^{1}$ To whom correspondence should be addressed:

Dr. Stephan Immenschuh, MD

Institut für Transfusionsmedizin

Medizinische Hochschule Hannover

Carl-Neuberg-Str. 1

30625 Hannover

Germany

Tel.: 49-511-532-6704/ -9714

Fax: 49-511-532-2079

e-mail: Immenschuh.Stephan@mh-hannover.de

* Supported by grant SFB547 A8 from the Deutsche Forschungsgemeinschaft (SI). 


\section{ABSTRACT}

Heme oxygenase $(\mathrm{HO})-1$ is the inducible isoform of the first and rate-limiting enzyme of heme degradation. Induction of $\mathrm{HO}-1$ protects against the cytotoxicity of oxidative stress and apoptotic cell death. More recently, HO-1 has been recognized to have major immunomodulatory and anti-inflammatory properties, which have been demonstrated in HO1 knockout mice and a human case of genetic HO-1 deficiency. Beneficial protective effects of HO-1 in inflammation are not only mediated via enzymatic degradation of proinflammatory free heme, but also via production of the anti-inflammatory compounds bilirubin and carbon monoxide. The immunomodulatory role of HO-1 is associated with its cell type-specific functions in myeloid cells (including macrophages and monocytes) and in endothelial cells, as both cell types are crucially involved in initiating inflammatory responses. This review covers the molecular mechanisms and signaling pathways that are involved in $\mathrm{HO}-1$ gene expression. In particular, it is discussed how key nuclear factors such as the redoxdependent transcriptional activators NF-E2 related factor 2 (Nrf2), NF-kB and AP-1 along with the transcription repressor BTB and CNC homologue 1 (Bach1) mediate inducible HO-1 gene expression. The role of central pro- and anti-inflammatory cellular signaling cascades including p38 MAPK and phosphatidylinositol-3 kinase (PI3K)/Akt in HO-1 regulation is highlighted. Finally, we summarize emerging strategies that apply targeted pharmacological induction of HO-1 for therapeutic interventions in inflammatory conditions.

\section{KEYWORDS}

Gene expression, heme oxygenase-1, immunomodulation, inflammation, oxidative stress, signaling. 


\section{INTRODUCTION}

Heme oxygenase $(\mathrm{HO})$ catalyzes the first and rate-limiting enzymatic step of heme degradation and produces carbon monoxide (CO), iron and biliverdin [1-3], which is converted into bilirubin (BR) via biliverdin reductase. Two genetically distinct $\mathrm{HO}$ isozymes, $\mathrm{HO}-1$ and $\mathrm{HO}-2$, are known. HO-2 represents the constitutive non-inducible isoform and is primarily expressed in brain and testis [4]. By contrast, the inducible isoform HO-1, which exhibits low basal expression levels in most cells and tissues, is highly up-regulated by a wide variety of oxidative stress stimuli. Due to its regulatory pattern, induction of HO-1 has generally been considered to be an adaptive cellular response against the toxicity of oxidative stress [5-10]. More recently, HO-1 has also been recognized to exhibit important immunmodulatory and anti-inflammatory functions. A potential link between HO-1 and inflammation has initially been shown in an animal model, in which specific up-regulation of $\mathrm{HO}$ enzyme activity attenuated complement-dependent inflammation [11]. Shortly thereafter, it has been demonstrated in a HO-1 knockout mouse model that these animals develop a chronic inflammatory disease and are highly vulnerable to an experimental sepsis induced by the classical pro-inflammatory mediator endotoxin [12]. Importantly, phenotypical alterations in the only known human case of genetic HO-1 deficiency are highly similar to those observed in HO-1 knockout mice [13]. By contrast, HO-2 deficient mice have an intact immune system, but exhibit major neurological defects [14]. Independently, targeted overexpression of HO-1 has been shown to have beneficial effects in various experimental animal models of inflammation [2, 15]. Due to the critical role of HO-1 in immunological responses [16-18], the mechanisms of its immunomodulatory functions are currently under intense investigation.

In this review, we discuss the current understanding of how HO-1 may mediate its antiinflammatory effects in myeloid and endothelial cells. Moreover, we summarize the regulatory role of major transcription factors (TFs) and signaling pathways that govern the inducible HO-1 gene expression. Finally, we highlight the therapeutic potential of targeted pharmacological induction of $\mathrm{HO}-1$. 


\section{Cell-specific immunomodulatory functions of HO-1 in myeloid and endothelial cells}

Inflammation is a complex reaction of the immune system in vascularized tissues at sites of an infection, toxin exposure or cell injury. Although HO-1 is expressed in all cells and tissues the salutary anti-inflammatory effects of HO-1 appear to be critically dependent on its cell type-specific functions in myeloid and endothelial cells.

\subsection{Myeloid cells}

Myeloid cells comprise monocytes, macrophages and dendritic cells, which play crucial regulatory roles in the innate and adaptive immune system [19]. For example, macrophages ingest and kill invading microorganisms as a first line of defense and are activated by various immunological stimuli such as microbial products and cytokines to initiate inflammatory immune responses [20]. In rodent macrophages, $\mathrm{HO}-1$ has been shown to be up-regulated by lipopolysaccharide (LPS) [21-23], which then attenuates the expression of various proinflammatory genes including cyclooxygenase-2, inducible nitric oxide (NO) synthase (iNOS), tumor necrosis factor (TNF)- $\alpha$ or interleukin (IL)-6 [18, 24] (Figure 1). In contrast to the LPS-dependent induction of HO-1 in rodent macrophages, gene expression of HO-1 is down-regulated by treatment with LPS in human monocytes [25]. More recently, the myeloid cell-specific immunomodulatory functions of $\mathrm{HO}-1$ have also been investigated in a conditional HO-1 knockout mouse model. Mice with myeloid cell-specific genetic HO-1 deficiency exhibited a defect of the interferon- $\beta$ pathway along with pathological immune responses in experimentally induced infections and an experimental autoimmune encephalomyelitis [26]. Finally, HO-1 is also important for the function of dendritic cells, which are the main cell population for antigen-presentation and for intiation of adaptive immune responses. Specifically, targeted up-regulation of $\mathrm{HO}-1$ has been shown to modulate maturation and cell-specific functions of dendritic cells in human and mouse models [17, 27]. In conclusion, HO-1 appears to have versatile functions via immunomodulation of myeloid cells. 


\subsection{Endothelial cells}

Endothelial monolayers are intimately linked with inflammation, because they constitute a barrier between the peripheral blood stream and inflamed tissues. The endothelium regulates recruitment and transmigration of immunologically active blood cells such as polymorphonuclear leukocytes and T lymphocytes to the site of an inflammation [28, 29]. HO-1 has been shown to directly affect the cellular interactions of polymorphonuclear leukocytes with endothelial cells in an in vivo rat model, in which increased $\mathrm{HO}$ activity downregulated the adhesion of these cells during experimental oxidative stress conditions [30]. Independently, major pathological alterations of the endothelium have been observed in HO1 knockout mice, in which endothelial cells were more susceptible to apoptotic cell death and denudation from the extracellular matrix [31]. Independently, anti-inflammatory endothelial protection via HO-1 has been shown to be mediated via its ability to down-regulate TNF $\alpha$ induced expression of various adhesion molecules [32, 33]. More recently, it has been reported that HO-1 was involved in the recruitment of endothelial progenitor cells to the site of an experimental vascular injury in various animal models [34].

Thus, HO-1 counteracts inflammatory reactions via modulation of various endothelial cell functions.

\section{Anti-inflammatory functions of HO-1: degradation of proinflammatory free heme and production of the anti-inflammatory compounds BR and CO}

The mechanisms that mediate the anti-inflammatory effects of $\mathrm{HO}-1$ are not understood in detail. It has been appreciated in recent years, however, that the enzymatic degradation of proinflammatory free heme and the production of the anti-inflammatory compounds biliverdin/BR and CO may play major roles to counteract inflammatory reactions.

Heme consists of a tetrapyrrole ring with a central iron ion and is an abundant compound in mammalians with contradictory biological functions. On the one hand, heme plays a physiological role for oxygen and mitochondrial electron transport as an essential prosthetic group of hemoglobin, myoglobin and cytochromes [35, 36]. On the other hand, non-protein 
bound free heme is highly toxic as it may cause oxidative stress. Due to the prooxidant properties of free heme, which have been shown in various animal and cell culture models, the enzymatic synthesis and degradation of this molecule is tightly controlled [35, 37, 38]. More recently, free heme has also been shown to have proinflammatory properties [10, 15, 39]. For example, heme has been demonstrated to be responsible for the increased influx of leukocytes into organs during an experimental inflammation in vivo [40]. Detrimental proinflammatory effects of free heme have also been shown in an animal model of experimental cerebral malaria, in which the heme-dependent detrimental effects were more pronounced in HO-1 deficient mice [41]. Thus, it is conceivable that the enzymatic degradation of proinflammatory free heme via HO-1 plays a critical role for the antiinflammatory functions of $\mathrm{HO}-1$ [10, 15, 37-39].

The role of BR as a beneficial compound with potent antioxidant and anti-inflammatory effects has only been appreciated in recent years [42, 43]. Protection against experimental inflammation via HO-1-derived biliverdin has been shown in animal models of proinflammatory cardiovascular [30] and gastrointestinal disorders [44]. Independently, beneficial effects of $B R$ have directly been implicated in the protection against endothelial activation and dysfunction in human aortic endothelial cells [45]. Interestingly, BR has also been suggested to specifically reduce leukocyte transmigration to the site of an experimental inflammation via interaction with adhesion molecules [46].

Although $\mathrm{CO}$ is generally considered a toxic gas, it has been recognized to have major physiological functions as a signaling molecule $[3,47,48]$. Specifically, HO-1-derived $\mathrm{CO}$ has been shown to be involved in the regulation of apoptosis, vasodilation and inflammation. In an early report on the potential protective effects of this gas, administration of exogenous $\mathrm{CO}$ blocked the LPS-induced production of proinflammatory cytokines via modulation of p38 MAP kinase [24]. Similar to the signaling gas NO, CO up-regulates the production of cGMP and this mechanism has been implicated in other functions of $\mathrm{CO}$ such as vasodilation and blockage of smooth muscle cell proliferation. Major potential for future therapeutic 
applications may have CO-releasing molecules (CORMs), which are compounds that deliver $\mathrm{CO}$ to its target sites without the toxicity of gaseous $\mathrm{CO}[49,50]$.

In summary, HO-1 counteracts inflammatory responses via metabolic conversion of proinflammatory free heme and production of the anti-inflammatory compounds BR and $\mathrm{CO}$.

\section{Redox-dependent TFs mediate the inducible HO-1 gene expression}

Targeted modulation of $\mathrm{HO}-1$ for potential anti-inflammatory therapeutic interventions not only requires detailed knowledge of the immunomodulatory effects of $\mathrm{HO}-1$. To achieve this goal, it is also necessary to precisely understand the mechanisms that regulate $\mathrm{HO}-1$ gene expression.

$\mathrm{HO}-1$ is induced by a plethora of physiological and pathological stimuli including oxidative stress signals, cytokines, bacterial compounds and growth factors. HO-1 expression is primarily regulated on the transcriptional level and multiple cis-acting regulatory elements (REs) of the HO-1 promoter have been shown to mediate the basal and inducible $\mathrm{HO}-1$ gene expression in different species (reviewed in $[2,8,9,51]$ ). Two upstream enhancer regions, which are termed E1 and E2, play major functional roles for redox-dependent induction of HO-1 [52, 53]. Both E1 and E2 enhancer regions contain several antioxidant response elements (AREs), which have also been identified in the promoters of other stress-inducible antioxidant and phase 2 detoxifying genes [54, 55]. An important difference between the rodent and human HO-1 genes with major biological relevance is a GT-microsatellite polymorphism, which is localized in the proximal human HO-1 gene promoter region. Lower numbers of GT repeats within this polymorphic sequence have been associated with higher inducibility of HO-1 gene expression in response to stress stimuli [56] and individuals with this allele seem to be protected against cardiovascular disorders (reviewed in [57]). In the following, we highlight the critical role of the major redox-dependent TFs NF-E2-related factor 2 (Nrf2), BTB and CNC homologue 1 (Bach1), NF-kB and AP-1 in regulating the inducible $\mathrm{HO}-1$ gene expression. 


\subsection{The Keap1/Nrf2 system}

Redox-dependent transcriptional induction of $\mathrm{HO}-1$ is primarily mediated through the cap'n'collar (CNC) TF Nrf2 [58], which was initially identified while screening for proteins that interact with the NF-E2 binding motif [59]. Nrf2 forms heterodimers with small Maf proteins and up-regulates a program of inducible protective genes via interaction with AREs $[55,60]$. Activation of Nrf2 by oxidative stress is mainly controlled by the cytosolic inhibitor Kelch-like $\mathrm{ECH}$-associated protein 1 (Keap1)[61, 62], also termed inhibitor of Nrf2 [63](Figure 2). Numerous prooxidant stimuli cause dissociation of Nrf2 from Keap1, which then permits subsequent nuclear translocation of Nrf2 [63, 64]. In a zebrafish model it has been demonstrated that various chemicals activate Nrf2 in a compound-specific manner via the modulation of various regulatory sites of Keap1 [65]. More recently, the Keap1/Nrf2 pathway has also been shown to be activated by the regulator protein $\mathrm{p} 62$ in experimental conditions that cause autophagy [66]. Thus, the Keap $1 / \mathrm{Nrf2}$ system appears to be a central sensor for a broad spectrum of unfavourable cellular conditions.

It is important to point out, that the Keap1/Nrf2 module may not only be regulated by prooxidant stimuli, but also by stress-independent signals such as glycogen synthase kinase (GSK)-3ß-dependent phosphorylation (Figure 3). Finally, it is not clear whether Nrf2dependent induction of $\mathrm{HO}-1$ is part of a general Nrf2-regulated antioxidant response that includes other Keap1/Nrf2-regulated genes such as $\mathrm{NAD}(\mathrm{P}) \mathrm{H}$ :oxidoreductase or thioredoxin reductase-1. A potential mechanism that could mediate Nrf2-specific induction of HO-1 involves the brahma-related gene 1 (BRG1). BRG1 has been shown to be necessary for the specific recruitment of Nrf2 to the promoter of the HO-1 gene, but not to that of other phase 2 detoxifying genes [67].

In conclusion, the redox-dependent Keap1/Nrf2 system plays a central role for $\mathrm{HO}-1$ induction in response to oxidativ stress. 


\subsection{The transcription repressor Bach1}

The transcription repressor Bach1 has been recognized to be a key regulator of the inducible HO-1 gene expression (Figure 2). Bach1 was initially identified as a regulator of globin gene expression in erythroid cells [68]. Similar to Nrf2, Bach1 belongs to the CNC family of TFs and forms heterodimers with small Maf proteins that bind to Maf recognition elements [60, 69] such as AREs of the HO-1 promoter. In contrast to Nrf2, Bach1 has six heme regulatory motifs, which are crucial for its regulatory functions. Bach1 has initially been shown to repress $\mathrm{HO}-1$ gene expression in the presence of low levels of intracellular heme. When intracellular heme levels are elevated, Bach1 changes its conformation and dissociates from the HO-1 promoter, allowing Nrf2 to bind to the ARE and to activate HO-1 gene expression [70] (Figure 2). More recently, heme has also been shown to control cellular Bach1 protein levels via a mechanism that involves proteasomal degradation of this protein [71]. As free heme exhibits major proinflammatory effects, it is conceivable that Bach1 might play a regulatory role in inflammation. In line with this notion, a regulatory link between Bach1 and the proinflammatory cytokine IL-6 has recently been elucidated in Bach1 knockout mice in the context of hyperoxic lung injury [72].

Bach1 does not only regulate HO-1 gene expression by heme, but also by other prooxidant compounds such as cadmium [73], diamide [74] and sodium arsenite [75]. More recently, the regulatory role of Bach1 in stress-dependent HO-1 induction has also been shown to be dependent on the differentiation status of keratinocytes in cell culture [76].

The interplay between Bach1 and Nrf2 to regulate HO-1 gene expression is discussed controversially. As an example, sodium arsenite has been shown to cause Bach1-specific $\mathrm{HO}-1$ induction independent from Nrf2, whereas sodium arsenite-dependent regulation via this mechanism was not observed for other ARE-regulated genes such as thioredoxin reductase-1 [75]. Similarly, it has recently been demonstrated that knockdown of Bach1 in human keratinocytes specifically up-regulated gene expression of $\mathrm{HO}-1$, but not that of other Nrf2-regulated genes [77]. In contrast, other investigators have reported that Bach1 induced HO-1 gene expression in coordination with a subset of other Nrf2-regulated genes [78, 79]. 
In conclusion, the interplay of Bach1 and Nrf2 is crucial for the redox-dependent $\mathrm{HO}-1$

induction and might give this system a high range of plasticity to adapt to adverse cellular conditions.

\subsection{NF-kB}

The NF-kB/Rel family of proteins comprises several TFs that regulate the inducible gene expression of various immunological and antioxidant protective responses including the upregulation of major proinflammatory cytokines, adhesion molecules and antioxidant stress proteins $[80,81]$. Under basal conditions NF-kB is contained in the cytoplasm by inhibitor of NF-KB (I-KB). In response to multiple signals the regulatory NF- $\mathrm{KB}$ subunits $\mathrm{p} 50$ and p65 dissociate from I-KB and subsequently translocate to the nucleus $[82,83]$. Although NF-kB has been shown to be induced by stimuli that are also known to up-regulate HO-1 gene expression, the role of this TF in $\mathrm{HO}-1$ gene regulation has been discussed controversially. This might be explained by the fact that functional $\kappa \mathrm{B}$-elements have remained elusive for $\mathrm{a}$ long while, because indirect approaches including computer-based sequence predictions, treatment with pharmacological NF- $\mathrm{kB}$ inhibitors and dominant negative mutants of $\mathrm{I}-\mathrm{\kappa B}$ have been applied in most studies.

In two recent reports functional binding sites for NF-kB of the promoters of the rat and mouse HO-1 genes have been identified. $\mathrm{A}$ KB element of the proximal rat $\mathrm{HO}-1$ gene promoter region has been shown to control $\mathrm{HO}-1$ up-regulation by the phorbol ester phorbol myrisate acetate (PMA), which is an activator of macrophages. PMA-dependent up-regulation of HO-1 gene expression was not observed in cells from mice, which were deficient for the NF-KB subunit p65 and was mediated via an I-kB-kinase-independent pathway [84]. Moreover, Li and colleagues have described a functional $\mathrm{kB}$ element in the mouse $\mathrm{HO}-1$ promoter. These authors have shown that a mechanism involving the NF-kB subunits $p 50$ and p65 as well as the inducible NO-synthase mediated $\mathrm{HO}-1$ up-regulation in vivo [85].

In summary, NF-кB appears to be directly involved in the induction of $\mathrm{HO}-1$ gene expression. 


\subsection{Activating protein-1 (AP-1)}

The TF AP-1 is composed of structurally and functionally related members of the Jun (c-Jun, JunB and JunD), Fos (c-Fos, FosB, Fra1 and Fra2) and activating TF (ATF) protein families. Dimers of these proteins regulate gene expression via interaction with AP-1 sites, which are also known as TPA-responsive elements (TREs). Inducible gene expression via AP-1 has been shown to be involved in a diverse range of cellular responses including immunological and antioxidant stress responses [86, 87]. Similar to NF-kB, AP-1 is up-regulated by a wide variety of prooxidant and pro-inflammatory stimuli. Alam and colleagues have initially reported that AP-1 played a crucial role for the induction of the mouse $\mathrm{HO}-1$ gene $[53,88]$. Subsequently, various functional AP-1 sites, which mediated inducer-dependent gene expression of $\mathrm{HO}-1$, have been identified in the promoter regions of the rat and human $\mathrm{HO}-1$ genes [51, 88-91]. Elucidation of the molecular mechanisms that are involved in AP-1dependent HO-1 gene regulation has turned out to be challenging for two major reasons. First, the classical AP-1 (TGATGCA) site is contained in the consensus sequence of AREs (TGCTGAGTCA), which are localized in the E1 and E2 regions of the HO-1 gene promoter and serve as major target sites for Nrf2 [58]. Cross-talk of Nrf2 with members of the AP-1 family, however, appears to be highly complex. As an example, c-Jun has recently been shown to directly interact with Nrf2 to activate the expression of the ARE-regulated genes

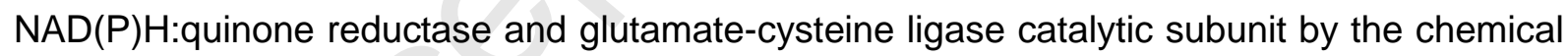
compound 4-hydroxy-2-nonenal [92]. Moreover, others have shown that Nrf2 might indirectly regulate the inducible expression of the glutamate-cysteine ligase catalytic subunit gene via activation of AP-1 [93]. Second, AP-1 sites in the HO-1 promoter mediate inducer-dependent HO-1 gene expression via mechanisms that involve synergistic cooperation of AP-1 with other TFs such as USF2 or SP-1. This has been shown for regulation of the rodent and human HO-1 genes in various cell culture models [94-97].

In summary, we have highlighted the role of various redox-dependent TFs that mediate the complex regulation of inducible HO-1 gene expression. Detailed overviews on this issue have also been given by others $[2,8,51]$. 


\section{Signaling cascades that mediate HO-1 gene regulation}

In general, activation of TFs is regulated by intracellular signaling cascades, which are controlled by modules of kinases/phosphatases and redox reactions. In the following, we highlight major signalling cascades that mediate HO-1 induction and are involved in the regulation of inflammatory immune responses.

\section{1. $\mathrm{p} 38 \mathrm{MAPK}$}

It has been known for many years that activation of MAPKs plays a central role for the induction of HO-1 gene expression [51] (Figure 3). Three major subfamilies of MAPK are known: extracellular signal-regulated kinase (ERK), c-Jun N-terminal kinase (JNK), and p38 MAPK [98]. While ERK is primarily considered to be activated in response to hormones and growth factors, JNK and p38 are primarily induced by stress-related stimuli [98, 99]. Due to space limitations, it is not intended to give a comprehensive overview on how various MAPKs might mediate HO-1 gene regulation, but rather discuss the specific role of p38 MAPK for HO-1 regulation.

Similar to HO-1, p38 MAPK has been shown to be involved in antioxidant and antiinflammatory responses. Not surprisingly, gene expression of HO-1 and p38 MAPK are activated by the same or similar stimuli. Numerous reports have demonstrated that inhibition of p38 activity by specific small molecule inhibitors, dominant negative mutants or gene silencing strategies blocked HO-1 induction in response to multiple stimuli [2, 9, 51] (Figure 3). Of note, the $\alpha$ and $\beta$ isoforms of p38 play counter-regulatory roles to the p38 $\gamma$ and $\delta$ isoforms, which has been demonstrated for sodium arsenite- and LPS-dependent induction of HO-1 [100, 101]. Unexpectedly and contradictory to what is generally thought on the activating role of $\mathrm{p} 38 \mathrm{MAPK}$ on $\mathrm{HO}-1$ gene expression, inhibition of $\mathrm{p} 38 \alpha$ has been demonstrated to up-regulate $\mathrm{HO}-1$ gene expression in human hepatoma cells via interaction with the TF Nrf2 [102, 103]. These findings have essentially been confirmed in an independent report, in which pharmacological inhibition and genetic deficiency of p38 $\alpha$ also up-regulated HO-1 gene expression [104]. Increased levels of HO-1 gene expression in 
p38 $\alpha$-deficient cells might be explained by the fact that these cells contain increased levels of intracellular ROS as compared to wild type cells [105]. Because p38 $\alpha$ is a sensor of ROS, cross-talk between $\mathrm{HO}-1$ and $\mathrm{p} 38 \alpha$ may have additional yet unknown functions in the context of oxidative stress and inflammation. It is also important to point out that p38 $\alpha$ is not only an upstream regulator of $\mathrm{HO}-1$, but that $\mathrm{p} 38 \alpha$ is also a downstream target of $\mathrm{HO}-1$. Silva and colleagues have demonstrated that increased HO-1 activity degraded $\mathrm{p} 38 \alpha$ in endothelial cells suggesting that these two molecules might form a physiological relevant feedback loop to regulate apoptosis [106].

In summary, p38 and HO-1 make up a closely linked signaling module with major regulatory functions in antioxidant and anti-inflammatory cellular responses.

\subsection{The phosphatidylinositol-3 kinase (PI3K)/Akt pathway}

$\mathrm{PI} 3 \mathrm{~K} / \mathrm{Akt}$ is an anti-apoptotic survival pathway and is regulated by a number of receptordependent mechanisms that are activated by growth factors and cytokines [107]. Moreover, in models of PI3K genetic deficiency an essential role of this kinase has been implicated in the regulation of inflammatory reactions [108]. Accumulating experimental evidence has indicated that activation of PI3K/Akt not only up-regulates HO-1 gene expression, but that the protective effects of this signaling cascade might be intimately linked with the salutary effects of HO-1 [109]. HO-1 gene expression has been shown to be up-regulated via PI3K/Akt in immunological cells in response to various signals such as prostaglandins or the pharmacological compounds [2, 94, 109, 110]. A more recent report has shown that HO-1 induction was mediated via activation of this signaling cascade by a mitochondrial redoxdependent pathway in vascular endothelial cells [111]. Finally, it has been suggested that $\mathrm{PI} 3 \mathrm{~K} / \mathrm{Akt}$ and GSK3 $\beta$ may have counter-regulatory functions in $\mathrm{HO}-1$ gene regulation. The complex interplay between these two kinases appears to involve mechanisms that control the nuclear localization of Nrf2 and Bach1[112, 113] (Figure 3). Details on the underlying regulatory mechanisms, however, are largely unknown. 
In conclusion, the PI3K/Akt cascade is a key mediator of $\mathrm{HO}-1$ induction in response to cytokines and growth factors.

\subsection{IL-10 and the Jak-STAT pathway}

The anti-inflammatory cytokine IL-10, which is a major inhibitor of activated macrophages and dendritic cells, has consistently been shown to induce HO-1 gene expression as reported by Lee and Chau [114] as well as by others [115-117]. Although the signaling cascades that couple HO-1 gene expression to the IL-10 receptor are not clear, activation of STAT3 has repeatedly been suggested to be involved in this regulatory pathway [116]. JakSTAT signaling plays a key role in the immune system and mediates major cytokineactivated pathways. In endothelial cells STAT3 has been shown to be necessary to mediate the HO-1 dependent protection against hyperoxic lung injury [118]. Functional STAT3 elements have recently been identified in the promoter regions of the rat [119] and human [120] HO-1 genes. Interestingly, a positive feedback circuit between IL-10 and HO-1 has been shown to be functional, which might amplify the anti-inflammatory effects of IL-10 in LPS-stimulated macrophages [114].

Taken together, the IL-10 pathway is an important regulator of $\mathrm{HO}-1$ gene expression in mononuclear cells.

\subsection{The toll-like receptor (TLR)-4 pathway}

HO-1 induction by LPS is mediated via (a) TLR-4 coupled pathway(s) and has been extensively studied in macrophages [21, 23]. Interestingly, Figueiredo and colleagues have recently demonstrated that heme led to $\mathrm{HO}-1$ gene expression via direct interaction with TLR-4 and suggested that this interaction could at least partially explain the proinflammatory LPS-like effects of heme [121]. HO-1 gene expression by LPS in macrophages is not only induced via a TLR-4-dependent mechanism, but increased HO-1 activity has also been shown to have inhibitory effects on intracellular signaling, that is initiated by TLR-4-activation. The inhibitory effect of $\mathrm{HO}-1$ on TLR-4 signaling could be regulated via $\mathrm{HO}-1$-derived $\mathrm{CO}$, 
which blocked translocation of TLR-4 into lipid rafts [122] and/or the interaction of TLR-4 with

the structural membrane protein caveolin-1 [123]. This regulatory interplay between TLR-4 and HO-1 appears to form a negative feedback loop, which might inhibit excessive activation of macrophages by LPS.

Taken together, activation of the central proinflammatory TLR-4 cascade leads to HO-1 gene activation and a negative feedback circuit in macrophages might be of major significance for the regulation of inflammatory responses.

\section{Pharmacological induction of $\mathrm{HO}-1$ as an anti-inflammatory therapeutic target}

A promising near term approach to apply $\mathrm{HO}-1$ for therapeutic interventions is the targeted induction of this inducible enzyme via pharmacological compounds. In the following, we discuss how pharmacological induction of $\mathrm{HO}-1$ might be applicable for specific antiinflammatory therapeutic interventions.

Metalloporphyrins such as cobalt protoporphyrin IX, which are prototypical inducers of $\mathrm{HO}-1$ and are commonly used in experimental cell culture and animal models, do not seem to be applicable for clinical interventions, because they lack cell-specificity and are severely toxic. Similarly, the $\mathrm{HO}$ substrate heme, which is one of the most potent inducers of $\mathrm{HO}-1$ and has been approved for the treatment of acute intermittent porphyria (heme arginate), only has limited potential for the treatment of inflammatory disorders. By contrast, a growing number of currently available pharmacologic compounds, which induce $\mathrm{HO}-1$ and are applied in standard therapies, might be useful for clinical interventions in inflammatory disorders. As an example, statins, which have initially been introduced to prevent atherosclerosis via their cholesterol-lowering effects, have recently also been recognized to exhibit anti-inflammatory effects via HO-1 induction [124, 125]. Moreover, treatment with 5-aminosalicylic acid (5ASA), which is one of the pharmacologic standard therapies of inflammatory bowel disease, has been shown to mediate its protective anti-inflammatory effects at least in part through up-regulation of HO-1 in an animal model of colitis [126]. Finally, various polyphenols, which are a group of antioxidant compounds and are currently investigated for their anti- 
inflammatory and anticancer activities, have been shown to provide anti-inflammatory protection via the induction of $\mathrm{HO}-1$ [127].

Due to the cell-type specific immunomodulatory effects of HO-1, targeted up-regulation of HO-1 in myeloid and endothelial cells seems to be a straightforward anti-inflammatory therapeutic option. In fact, accumulating evidence has demonstrated that specific $\mathrm{HO}-1$ induction in these cells protects against inflammatory reactions. As an example, it has recently been demonstrated in an in vivo rat model that cell-specific up-regulation of $\mathrm{HO}-1$ in liver tissue macrophages via the cytokine adiponectin protects against experimental ethanoldependent inflammation [117]. Other compounds, which have been shown to mediate myeloid cell-specific induction of $\mathrm{HO}-1$, are the cardiovascular hormone atrial natriuretic peptide [128] and the clinically applied antiprotease compound 4-(2-aminoethyl)benzenesulfonyl fluoride (AEBSF) [94]. Clearly, these compounds might be applicable to specifically induce HO-1 in myeloid cells for therapeutic interventions. In endothelial cells, quercetin and theaflavin have been shown to provide specific HO-1-dependent antiinflammatory protection in an ApoE knockout mouse model of atherosclerosis [129]. Moreover, it has recently been demonstrated that the nonsteroidal anti-inflammatory drug celecoxib provided specific anti-inflammatory effects in endothelial cells via induction of $\mathrm{HO}-1$ [111].

Finally, it is important to point out that targeted up-regulation of $\mathrm{HO}-1$ has failed to provide anti-inflammatory protection, when induced after the onset of inflammation. This has been shown in animal models of inflammatory bowel disease and pancreatitis, respectively. In either case HO-1 was only protective when induced before the onset of experimental inflammation $[130,131]$. These findings indicate that anti-inflammatory protection via HO-1 induction is questionable in established inflammation, but might be useful as a preventive measure.

In summary, targeted HO-1 induction in myeloid and endothelial cells has major antiinflammatory therapeutic potential. Therefore, identification and characterization of 
pharmacological compounds that induce HO-1 in a cell-specific and cell context-specific manner deserve further attention.

\section{6. $\quad$ Conclusions}

1. HO-1 plays key immunomodulatory and anti-inflammatory roles via its cell typespecific effects in myeloid and endothelial cells.

2. Critical functions of HO-1 are degradation of proinflammatory free heme and enzymatic production of the anti-inflammatory compounds $\mathrm{CO}$ and BR.

3. The inducible HO-1 gene regulation is mediated via an interplay of redoxdependent activating TFs and the transcription repressor Bach1, which are under the control of a complex network of signaling cascades.

4. Targeted induction of HO-1 in myeloid and endothelial cells has major therapeutic potential for the treatment of inflammatory disorders. 


\section{REFERENCES}

[1] Tenhunen R, Marver HS, Schmid R. The enzymatic conversion of heme to bilirubin by microsomal heme oxygenase. Proc Natl Acad Sci USA 1968;61:748-55.

[2] Ryter SW, Alam J, Choi AM. Heme oxygenase-1/carbon monoxide: from basic science to therapeutic applications. Physiol Rev 2006;86:583-650.

[3] Maines MD. The heme oxygenase system: a regulator of second messenger gases. Annu Rev Pharmacol Toxicol 1997;37:517-54.

[4] Trakshel GM, Kutty RK, Maines MD. Purification and characterization of the major constitutive form of testicular heme oxygenase. The noninducible isoform. J Biol Chem 1986;261:11131-7.

[5] Keyse SM, Applegate LA, Tromvoukis Y, Tyrrell RM. Oxidant stress leads to transcriptional activation of the human heme oxygenase gene in cultured skin fibroblasts. Mol Cell Biol 1990;10:4967-9.

[6] Vile GF, Basu-Modak S, Waltner C, Tyrrell RM. Heme oxygenase 1 mediates an adaptive response to oxidative stress in human skin fibroblasts. Proc Natl Acad Sci U S A 1994;91:2607-10.

[7] Otterbein LE, Choi AM. Heme oxygenase: colors of defense against cellular stress. Am J Physiol Lung Cell Mol Physiol 2000;279:L1029-37.

[8] Choi AM, Alam J. Heme oxygenase-1: function, regulation, and implication of a novel stress-inducible protein in oxidant-induced lung injury. Am J Respir Cell Mol Biol 1996;15:9-19.

[9] Immenschuh S, Ramadori G. Gene regulation of heme oxygenase-1 as a therapeutic target. Biochem Pharmacol 2000;60:1121-8.

[10] Gozzelino R, Jeney V, Soares MP. Mechanisms of cell protection by heme oxygenase-1. Annu Rev Pharmacol Toxicol 2010;50:323-54.

[11] Willis D, Moore AR, Frederick R, Willoughby DA. Heme oxygenase: a novel target for the modulation of the inflammatory response. Nat Med 1996;2:87-90.

[12] Poss KD, Tonegawa S. Reduced stress defense in heme oxygenase 1-deficient cells. Proc Natl Acad Sci U S A 1997;94:10925-30.

[13] Yachie A, Niida Y, Wada T, Igarashi N, Kaneda H, Toma T, et al. Oxidative stress causes enhanced endothelial cell injury in human heme oxygenase-1 deficiency. $J$ Clin Invest 1999;103:129-35.

[14] Burnett AL, Johns DG, Kriegsfeld LJ, Klein SL, Calvin DC, Demas GE, et al. Ejaculatory abnormalities in mice with targeted disruption of the gene for heme oxygenase-2. Nat Med 1998;4:84-7. 
[15] Soares MP, Marguti I, Cunha A, Larsen R. Immunoregulatory effects of HO-1: how does it work? Curr Opin Pharmacol 2009;9:482-9.

[16] George JF, Braun A, Brusko TM, Joseph R, Bolisetty S, Wasserfall CH, et al. Suppression by $\mathrm{CD} 4+\mathrm{CD} 25+$ regulatory $\mathrm{T}$ cells is dependent on expression of heme oxygenase-1 in antigen-presenting cells. Am J Pathol 2008;173:154-60.

[17] Remy S, Blancou P, Tesson L, Tardif V, Brion R, Royer PJ, et al. Carbon monoxide inhibits TLR-induced dendritic cell immunogenicity. J Immunol 2009;182:1877-84.

[18] Kapturczak MH, Wasserfall C, Brusko T, Campbell-Thompson M, Ellis TM, Atkinson MA, et al. Heme oxygenase-1 modulates early inflammatory responses: evidence from the heme oxygenase-1-deficient mouse. Am J Pathol 2004;165:1045-53.

[19] Geissmann F, Manz MG, Jung S, Sieweke MH, Merad M, Ley K. Development of monocytes, macrophages, and dendritic cells. Science 2010;327:656-61.

[20] Zhang X, Mosser DM. Macrophage activation by endogenous danger signals. J Pathol 2008;214:161-78.

[21] Otterbein L, Chin YB, Otterbein SL, Lowe VC, Fessler HE, Choi AMK. Mechanism of hemoglobin-induced protection against endotoxemia in rats: a ferritin-independent pathway. Am J Physiol 1997;272:L268-L75.

[22] Bauer I, Wanner GA, Rensing H, Alte C, Miescher EA, Wolf B, et al. Expression pattern of heme oxygenase isoenzymes 1 and 2 in normal and stress-exposed rat liver. Hepatology 1998;27:829-38.

[23] Immenschuh S, Tan M, Ramadori G. Nitric oxide mediates the lipopolysaccharide dependent upregulation of the heme oxygenase-1 gene expression in cultured rat Kupffer cells. J Hepatol 1999;30:61-9.

[24] Otterbein LE, Bach FH, Alam J, Soares M, Tao Lu H, Wysk M, et al. Carbon monoxide has anti-inflammatory effects involving the mitogen-activated protein kinase pathway. Nat Med 2000;6:422-8.

[25] Miyazaki T, Kirino Y, Takeno M, Samukawa S, Hama M, Tanaka M, et al. Expression of heme oxygenase- 1 in human leukemic cells and its regulation by transcriptional repressor Bach1. Cancer Sci 2010.

[26] Tzima S, Victoratos P, Kranidioti K, Alexiou M, Kollias G. Myeloid heme oxygenase-1 regulates innate immunity and autoimmunity by modulating IFN-beta production. $J$ Exp Med 2009;206:1167-79.

[27] Park DJ, Agarwal A, George JF. Heme Oxygenase-1 Expression in Murine Dendritic Cell Subpopulations. Effect on CD8+ Dendritic Cell Differentiation in Vivo. Am J Pathol 2010.

[28] Muller WA. Leukocyte-endothelial-cell interactions in leukocyte transmigration and the inflammatory response. Trends Immunol 2003;24:327-34. 
[29] Cook-Mills JM, Deem TL. Active participation of endothelial cells in inflammation. J Leukoc Biol 2005;77:487-95.

[30] Hayashi S, Takamiya R, Yamaguchi T, Matsumoto K, Tojo SJ, Tamatani T, et al. Induction of heme oxygenase-1 suppresses venular leukocyte adhesion elicited by oxidative stress: role of bilirubin generated by the enzyme. Circ Res 1999;85:663-71.

[31] True AL, Olive M, Boehm M, San H, Westrick RJ, Raghavachari N, et al. Heme oxygenase-1 deficiency accelerates formation of arterial thrombosis through oxidative damage to the endothelium, which is rescued by inhaled carbon monoxide. Circ Res 2007; 101:893-901.

[32] Liu X, Spolarics Z. Methemoglobin is a potent activator of endothelial cells by stimulating IL-6 and IL-8 production and E-selectin membrane expression. Am J Physiol Cell Physiol 2003;285:C1036-C46.

[33] Soares MP, Seldon MP, Gregoire IP, Vassilevskaia T, Berberat PO, Yu J, et al. Heme oxygenase-1 modulates the expression of adhesion molecules associated with endothelial cell activation. J Immunol 2004;172:3553-63.

[34] Wu BJ, Midwinter RG, Cassano C, Beck K, Wang Y, Changsiri D, et al. Heme oxygenase-1 increases endothelial progenitor cells. Arterioscler Thromb Vasc Biol 2009;29:1537-42.

[35] Wijayanti N, Katz N, Immenschuh S. Biology of heme in health and disease. Curr Med Chem 2004;11:981-6.

[36] Mense SM, Zhang L. Heme: a versatile signaling molecule controlling the activities of diverse regulators ranging from transcription factors to MAP kinases. Cell Res 2006;16:681-92.

[37] Ryter SW, Tyrrell RM. The heme synthesis and degradation pathways: role in oxidant sensitivity. Heme oxygenase has both pro- and antioxidant properties. Free Radical Biol Med 2000;28:289-309.

[38] Ponka P. Cell biology of heme. Am J Med Sci 1999;318:241-56.

[39] Wagener FA, Volk HD, Willis D, Abraham NG, Soares MP, Adema GJ, et al. Different faces of the heme-heme oxygenase system in inflammation. Pharmacol Rev 2003;55:551-71.

[40] Wagener FA, Abraham NG, van Kooyk Y, de Witte T, Figdor CG. Heme-induced cell adhesion in the pathogenesis of sickle-cell disease and inflammation. Trends Pharmacol Sci 2001;22:52-4.

[41] Pamplona A, Ferreira A, Balla J, Jeney V, Balla G, Epiphanio S, et al. Heme oxygenase- 1 and carbon monoxide suppress the pathogenesis of experimental cerebral malaria. Nat Med 2007;13:703-10. 
[42] Stocker R. Antioxidant activities of bile pigments. Antioxid Redox Signal 2004;6:8419.

[43] Kapitulnik J, Maines MD. Pleiotropic functions of biliverdin reductase: cellular signaling and generation of cytoprotective and cytotoxic bilirubin. Trends Pharmacol Sci 2009;30:129-37.

[44] Berberat PO, A-Rahim YI, Yamashita K, Warny MM, Csizmadia E, Robson SC, et al. Heme oxygenase-1-generated biliverdin ameliorates experimental murine colitis. Inflamm Bowel Dis 2005;11:350-9.

[45] Kawamura K, Ishikawa K, Wada Y, Kimura S, Matsumoto H, Kohro T, et al. Bilirubin from heme oxygenase-1 attenuates vascular endothelial activation and dysfunction. Arterioscler Thromb Vasc Biol 2005;25:155-60.

[46] Keshavan P, Deem TL, Schwemberger SJ, Babcock GF, Cook-Mills JM, Zucker SD. Unconjugated bilirubin inhibits VCAM-1-mediated transendothelial leukocyte migration. J Immunol 2005;174:3709-18.

[47] Boczkowski J, Poderoso JJ, Motterlini R. CO-metal interaction: Vital signaling from a lethal gas. Trends Biochem Sci 2006;31:614-21.

[48] Kim HP, Ryter SW, Choi AM. CO as a cellular signaling molecule. Annu Rev Pharmacol Toxicol 2006;46:411-49.

[49] Motterlini R, Clark JE, Foresti R, Sarathchandra P, Mann BE, Green CJ. Carbon monoxide-releasing molecules: characterization of biochemical and vascular activities. Circ Res 2002;90:E17-24.

[50] Motterlini R, Mann BE, Foresti R. Therapeutic applications of carbon monoxidereleasing molecules. Expert Opin Investig Drugs 2005;14:1305-18.

[51] Alam J, Cook JL. How many transcription factors does it take to turn on the heme oxygenase-1 gene? Am J Respir Cell Mol Biol 2007;36:166-74.

[52] Alam A. Multiple elements within the 5' distal enhancer of the mouse heme oxygenase-1 gene mediate induction by heavy metals. J Biol Chem 1994; 269:25049-56.

[53] Alam J, Camhi S, Choi AMK. Identification of a second region upstream of the mouse heme oxygenase-1 gene that functions as a basal level and inducer-dependent transcription enhancer. J Biol Chem 1995;270:11977-84.

[54] Nguyen T, Sherratt PJ, Pickett CB. Regulatory mechanisms controlling gene expression mediated by the antioxidant response element. Annu Rev Pharmacol Toxicol 2003;43:233-60.

[55] Kensler TW, Wakabayashi N, Biswal S. Cell survival responses to environmental stresses via the Keap1-Nrf2-ARE pathway. Annu Rev Pharmacol Toxicol 2007;47:89116. 
[56] Yamada N, Yamaya M, Okinaga S, Nakayama K, Sekizawa K, Shibahara S, et al. Microsatellite polymorphism in the heme oxygenase-1 gene promoter is associated with susceptibility to emphysema. Am J Hum Genet 2000;66:187-95.

[57] Exner M, Minar E, Wagner O, Schillinger M. The role of heme oxygenase-1 promoter polymorphisms in human disease. Free Radic Biol Med 2004;37:1097-104.

[58] Alam J, Stewart D, Touchard C, Boinapally S, Choi AM, Cook JL. Nrf2, a Cap'n'Collar transcription factor, regulates induction of the heme oxygenase-1 gene. J Biol Chem 1999;274:26071-8.

[59] Moi P, Chan K, Asunis I, Cao A, Kan YW. Isolation of NF-E2-related factor 2 (Nrf2), a NF-E2-like basic leucine zipper transcriptional activator that binds to the tandem NFE2/AP1 repeat of the beta-globin locus control region. Proc Natl Acad Sci U S A 1994;91:9926-30.

[60] Motohashi H, O'Connor T, Katsuoka F, Engel JD, Yamamoto M. Integration and diversity of the regulatory network composed of Maf and CNC families of transcription factors. Gene 2002;294:1-12.

[61] Itoh K, Wakabayashi N, Katoh Y, Ishii T, Igarashi K, Engel JD, et al. Keap1 represses nuclear activation of antioxidant response elements by Nrf2 through binding to the amino-terminal Neh2 domain. Genes Dev 1999;13:76-86.

[62] Kobayashi M, Yamamoto M. Molecular mechanisms activating the Nrf2-Keap1 pathway of antioxidant gene regulation. Antioxid Redox Signal 2005;7:385-94.

[63] Kaspar JW, Niture SK, Jaiswal AK. Nrf2:INrf2 (Keap1) signaling in oxidative stress. Free Radic Biol Med 2009;47:1304-9.

[64] Kimura M, Yamamoto T, Zhang J, Itoh K, Kyo M, Kamiya T, et al. Molecular basis distinguishing the DNA binding profile of Nrf2-Maf heterodimer from that of Maf homodimer. J Biol Chem 2007;282:33681-90.

[65] Kobayashi M, Li L, Iwamoto N, Nakajima-Takagi Y, Kaneko H, Nakayama Y, et al. The antioxidant defense system Keap1-Nrf2 comprises a multiple sensing mechanism for responding to a wide range of chemical compounds. Mol Cell Biol 2009;29:493-502.

[66] Komatsu M, Kurokawa H, Waguri S, Taguchi K, Kobayashi A, Ichimura Y, et al. The selective autophagy substrate $\mathrm{p} 62$ activates the stress responsive transcription factor Nrf2 through inactivation of Keap1. Nat Cell Biol 2010;12:213-23.

[67] Zhang J, Ohta T, Maruyama A, Hosoya T, Nishikawa K, Maher JM, et al. BRG1 interacts with $\mathrm{Nrf} 2$ to selectively mediate $\mathrm{HO}-1$ induction in response to oxidative stress. Mol Cell Biol 2006;26:7942-52.

[68] Oyake T, Itoh K, Motohashi H, Hayashi N, Hoshino H, Nishizawa M, et al. Bach proteins belong to a novel family of BTB-basic leucine zipper transcription factors that 
interact with MafK and regulate transcription through the NF-E2 site. Mol Cell Biol 1996;16:6083-95.

[69] Igarashi K, Sun J. The heme-Bach1 pathway in the regulation of oxidative stress response and erythroid differentiation. Antioxid Redox Signal 2006;8:107-18.

[70] Ogawa K, Sun J, Taketani S, Nakajima O, Nishitani C, Sassa S, et al. Heme mediates derepression of Maf recognition element through direct binding to transcription repressor Bach1. Embo J 2001;20:2835-43.

[71] Zenke-Kawasaki Y, Dohi Y, Katoh Y, Ikura T, Ikura M, Asahara T, et al. Heme induces ubiquitination and degradation of the transcription factor Bach1. Mol Cell Biol 2007;27:6962-71.

[72] Tanimoto T, Hattori N, Senoo T, Furonaka M, Ishikawa N, Fujitaka K, et al. Genetic ablation of the Bach1 gene reduces hyperoxic lung injury in mice: role of IL-6. Free Radic Biol Med 2009;46:1119-26.

[73] Suzuki H, Tashiro S, Sun J, Doi H, Satomi S, Igarashi K. Cadmium induces nuclear export of Bach1, a transcriptional repressor of heme oxygenase-1 gene. J Biol Chem 2003;278:49246-53.

[74] Ishikawa M, Numazawa S, Yoshida T. Redox regulation of the transcriptional repressor Bach1. Free Radic Biol Med 2005;38:1344-52.

[75] Reichard JF, Sartor MA, Puga A. BACH1 is a specific repressor of HMOX1 that is inactivated by arsenite. J Biol Chem 2008;283:22363-70.

[76] Okada S, Muto A, Ogawa E, Nakanome A, Katoh Y, Ikawa S, et al. Bach1-dependent and -independent regulation of heme oxygenase-1 in keratinocytes. J Biol Chem 2010.

[77] MacLeod AK, McMahon M, Plummer SM, Higgins LG, Penning TM, Igarashi K, et al. Characterization of the cancer chemopreventive NRF2-dependent gene battery in human keratinocytes: demonstration that the KEAP1-NRF2 pathway, and not the BACH1-NRF2 pathway, controls cytoprotection against electrophiles as well as redox-cycling compounds. Carcinogenesis 2009;30:1571-80.

[78] Hintze KJ, Katoh Y, Igarashi K, Theil EC. Bach1 repression of ferritin and thioredoxin reductase 1 is heme-sensitive in cells and in vitro and coordinates expression with heme oxygenase1, beta-globin, and $\operatorname{NADP}(H)$ quinone (oxido) reductase1. J Biol Chem 2007;282:34365-71.

[79] Dhakshinamoorthy S, Jain AK, Bloom DA, Jaiswal AK. Bach1 competes with Nrf2 leading to negative regulation of the antioxidant response element (ARE)-mediated $\mathrm{NAD}(\mathrm{P}) \mathrm{H}$ :quinone oxidoreductase 1 gene expression and induction in response to antioxidants. J Biol Chem 2005;280:16891-900. 
[80] Perkins ND, Gilmore TD. Good cop, bad cop: the different faces of NF-kappaB. Cell Death Differ 2006;13:759-72.

[81] Gilmore TD. Introduction to NF-kappaB: players, pathways, perspectives. Oncogene 2006;25:6680-4.

[82] Ghosh S, Hayden MS. New regulators of NF-kappaB in inflammation. Nat Rev Immunol 2008;8:837-48.

[83] Chen LF, Greene WC. Shaping the nuclear action of NF-kappaB. Nat Rev Mol Cell Biol 2004;5:392-401.

[84] Naidu S, Wijayanti N, Santoso S, Kietzmann T, Immenschuh S. An atypical NF-kappa B-regulated pathway mediates phorbol ester-dependent heme oxygenase-1 gene activation in monocytes. J Immunol 2008;181:4113-23.

[85] Li Q, Guo Y, Ou Q, Cui C, Wu WJ, Tan W, et al. Gene transfer of inducible nitric oxide synthase affords cardioprotection by upregulating heme oxygenase-1 via a nuclear factor-\{kappa\}B-dependent pathway. Circulation 2009;120:1222-30.

[86] Karin M. The regulation of AP-1 activity by mitogen-activated protein kinases. J Biol Chem 1995;270:16483-6.

[87] Hess J, Angel P, Schorpp-Kistner M. AP-1 subunits: quarrel and harmony among siblings. J Cell Sci 2004;117:5965-73.

[88] Alam J, Den Z. Distal AP-1 binding sites mediate basal level enhancement and TPA induction of the mouse heme oxygenase-1 gene. J Biol Chem 1992;267:21894-900.

[89] Immenschuh S, Hinke V, Ohlmann A, Gifhorn-Katz S, Katz N, Jungermann K, et al. Transcriptional activation of the haem oxygenase- 1 gene by cGMP via a cAMP response element/activator protein-1 element in primary cultures of rat hepatocytes. Biochem J 1998;334 ( Pt 1):141-6.

[90] Hock TD, Liby K, Wright MM, McConnell S, Schorpp-Kistner M, Ryan TM, et al. JunB and JunD regulate human heme oxygenase-1 gene expression in renal epithelial cells. J Biol Chem 2007;282:6875-86.

[91] Immenschuh S, Hinke V, Katz N, Kietzmann T. Transcriptional induction of the heme oxygenase-1 gene expression by okadaic acid in primary rat hepatocyte cultures. Mol Pharmacol 2000;57:610-8.

[92] Levy S, Jaiswal AK, Forman HJ. The role of c-Jun phosphorylation in EpRE activation of phase II genes. Free Radic Biol Med 2009;47:1172-9.

[93] Yang H, Magilnick N, Lee C, Kalmaz D, Ou X, Chan JY, et al. Nrf1 and Nrf2 regulate rat glutamate-cysteine ligase catalytic subunit transcription indirectly via NF-kappaB and AP-1. Mol Cell Biol 2005;25:5933-46.

[94] Wijayanti N, Kietzmann T, Immenschuh S. Heme oxygenase-1 gene activation by the $\mathrm{NAD}(\mathrm{P}) \mathrm{H}$ oxidase inhibitor 4-(2-aminoethyl) benzenesulfonyl fluoride via a protein 

2005;280:21820-9.

[95] Samoylenko A, Dimova E, Teplyuk N, Immenschuh S, Kietzmann T. Opposite expression of the antioxidant heme oxygenase- 1 in primary cells and tumor cells: regulation by interaction of USF-2 and Fra-1. Antioxid Redox Signal 2008;in press.

[96] Wright MM, Kim J, Hock TD, Leitinger N, Freeman BA, Agarwal A. Human haem oxygenase-1 induction by nitro-linoleic acid is mediated by CAMP, AP-1 and E-box response element interactions. Biochem J 2009;422:353-61.

[97] Deshane J, Kim J, Bolisetty S, Hock TD, Hill-Kapturczak N, Agarwal A. Sp1 regulates chromatin looping between an intronic enhancer and distal promoter of the human heme oxygenase-1 gene in renal cells. J Biol Chem 2010;285:16476-86.

[98] Kyriakis JM, Avruch J. Mammalian mitogen-activated protein kinase signal transduction pathways activated by stress and inflammation. Physiol Rev 2001;81:807-69.

[99] Wagner EF, Nebreda AR. Signal integration by JNK and p38 MAPK pathways in cancer development. Nat Rev Cancer 2009;9:537-49.

[100] Kietzmann T, Samoylenko A, Immenschuh S. Transcriptional regulation of heme oxygenase-1 gene expression by MAP kinases of the JNK and p38 pathways in primary cultures of rat hepatocytes. J Biol Chem 2003;278:17927-36.

[101] Wijayanti N, Huber S, Samoylenko A, Kietzmann T, Immenschuh S. Role of NFkappaB and p38 MAP kinase signaling pathways in the lipopolysaccharide-dependent activation of heme oxygenase-1 gene expression. Antioxid Redox Signal 2004;6:80210.

[102] Yu R, Mandlekar S, Lei W, Fahl WE, Tan TH, Kong AN. p38 mitogen-activated protein kinase negatively regulates the induction of phase II drug-metabolizing enzymes that detoxify carcinogens. J Biol Chem 2000;275:2322-7.

[103] Keum YS, Yu S, Chang PP, Yuan X, Kim JH, Xu C, et al. Mechanism of action of sulforaphane: inhibition of p38 mitogen-activated protein kinase isoforms contributing to the induction of antioxidant response element-mediated heme oxygenase-1 in human hepatoma HepG2 cells. Cancer Res 2006;66:8804-13.

[104] Naidu S, Vijayan V, Santoso S, Kietzmann T, Immenschuh S. Inhibition and genetic deficiency of p38 MAPK up-regulates heme oxygenase-1 gene expression via Nrf2. J Immunol 2009;182:7048-57.

[105] Dolado I, Swat A, Ajenjo N, De Vita G, Cuadrado A, Nebreda AR. p38alpha MAP kinase as a sensor of reactive oxygen species in tumorigenesis. Cancer Cell 2007;11:191-205. 
[106] Silva G, Cunha A, Gregoire IP, Seldon MP, Soares MP. The antiapoptotic effect of heme oxygenase- 1 in endothelial cells involves the degradation of p38 alpha MAPK isoform. J Immunol 2006;177:1894-903.

[107] Koyasu S. The role of PI3K in immune cells. Nat Immunol 2003;4:313-9.

[108] Ghigo A, Damilano F, Braccini L, Hirsch E. PI3K inhibition in inflammation: Toward tailored therapies for specific diseases. Bioessays 2010;32:185-96.

[109] Martin D, Rojo Al, Salinas M, Diaz R, Gallardo G, Alam J, et al. Regulation of heme oxygenase-1 expression through the phosphatidylinositol 3-kinase/Akt pathway and the Nrf2 transcription factor in response to the antioxidant phytochemical carnosol. $J$ Biol Chem 2004;279:8919-29.

[110] Alvarez-Maqueda M, El Bekay R, Alba G, Monteseirin J, Chacon P, Vega A, et al. 15deoxy-delta 12,14-prostaglandin $\mathrm{J} 2$ induces heme oxygenase-1 gene expression in a reactive oxygen species-dependent manner in human lymphocytes. J Biol Chem 2004;279:21929-37.

[111] Hamdulay SS, Wang B, Birdsey GM, Ali F, Dumont O, Evans PC, et al. Celecoxib activates $\mathrm{PI}-3 \mathrm{~K} / \mathrm{Akt}$ and mitochondrial redox signaling to enhance heme oxygenase1-mediated anti-inflammatory activity in vascular endothelium. Free Radic Biol Med 2010;48:1013-23.

[112] Salazar M, Rojo Al, Velasco D, de Sagarra RM, Cuadrado A. Glycogen synthase kinase-3beta inhibits the xenobiotic and antioxidant cell response by direct phosphorylation and nuclear exclusion of the transcription factor Nrf2. J Biol Chem 2006;281:14841-51.

[113] Kaspar JW, Jaiswal AK. Antioxidant-induced phosphorylation of tyrosine 486 leads to rapid nuclear export of Bach1 that allows Nrf2 to bind to the antioxidant response element and activate defensive gene expression. J Biol Chem 2010;285:153-62.

[114] Lee TS, Chau LY. Heme oxygenase-1 mediates the anti-inflammatory effect of interleukin-10 in mice. Nat Med 2002;8:240-6.

[115] Chen S, Kapturczak MH, Wasserfall C, Glushakova OY, Campbell-Thompson M, Deshane JS, et al. Interleukin 10 attenuates neointimal proliferation and inflammation in aortic allografts by a heme oxygenase-dependent pathway. Proc Natl Acad Sci U S A 2005;102:7251-6.

[116] Ricchetti GA, Williams LM, Foxwell BM. Heme oxygenase 1 expression induced by IL-10 requires STAT-3 and phosphoinositol-3 kinase and is inhibited by lipopolysaccharide. J Leukoc Biol 2004;76:719-26.

[117] Mandal P, Park PH, McMullen MR, Pratt BT, Nagy LE. The anti-inflammatory effects of adiponectin are mediated via a heme oxygenase-1-dependent pathway in rat Kupffer cells. Hepatology 2010;51:1420-9. 
[118] Zhang X, Shan P, Jiang G, Zhang SS, Otterbein LE, Fu XY, et al. Endothelial STAT3 is essential for the protective effects of $\mathrm{HO}-1$ in oxidant-induced lung injury. Faseb $\mathrm{J}$ 2006;20:2156-8.

[119] Tron K, Samoylenko A, Musikowski G, Kobe F, Immenschuh S, Schaper F, et al. Regulation of rat heme oxygenase- 1 expression by interleukin- 6 via the Jak/STAT pathway in hepatocytes. J Hepatol 2006;45:72-80.

[120] Weis N, Weigert A, von Knethen A, Brune B. Heme oxygenase-1 contributes to an alternative macrophage activation profile induced by apoptotic cell supernatants. Mol Biol Cell 2009;20:1280-8.

[121] Figueiredo RT, Fernandez PL, Mourao-Sa DS, Porto BN, Dutra FF, Alves LS, et al. Characterization of heme as activator of Toll-like receptor 4. J Biol Chem 2007;282:20221-9.

[122] Nakahira K, Kim HP, Geng XH, Nakao A, Wang X, Murase N, et al. Carbon monoxide differentially inhibits TLR signaling pathways by regulating ROS-induced trafficking of TLRs to lipid rafts. J Exp Med 2006;203:2377-89.

[123] Wang XM, Kim HP, Nakahira K, Ryter SW, Choi AM. The heme oxygenase-1/carbon monoxide pathway suppresses TLR4 signaling by regulating the interaction of TLR4 with caveolin-1. J Immunol 2009;182:3809-18.

[124] Lee TS, Chang CC, Zhu Y, Shyy JY. Simvastatin induces heme oxygenase-1: a novel mechanism of vessel protection. Circulation 2004;110:1296-302.

[125] Grosser N, Hemmerle A, Berndt G, Erdmann K, Hinkelmann U, Schurger S, et al. The antioxidant defense protein heme oxygenase 1 is a novel target for statins in endothelial cells. Free Radic Biol Med 2004;37:2064-71.

[126] Horvath K, Varga C, Berko A, Posa A, Laszlo F, Whittle BJ. The involvement of heme oxygenase- 1 activity in the therapeutic actions of 5-aminosalicylic acid in rat colitis. Eur J Pharmacol 2008;581:315-23.

[127] Rahman I, Biswas SK, Kirkham PA. Regulation of inflammation and redox signaling by dietary polyphenols. Biochem Pharmacol 2006;72:1439-52.

[128] Kiemer AK, Gerwig T, Gerbes AL, Meissner H, Bilzer M, Vollmar AM. Kupffer-cell specific induction of heme oxygenase 1 (hsp32) by the atrial natriuretic peptide-role of cGMP. J Hepatol 2003;38:490-8.

[129] Loke WM, Proudfoot JM, Hodgson JM, McKinley AJ, Hime N, Magat M, et al. Specific dietary polyphenols attenuate atherosclerosis in apolipoprotein E-knockout mice by alleviating inflammation and endothelial dysfunction. Arterioscler Thromb Vasc Biol 2010;30:749-57. 
[130] Paul G, Bataille F, Obermeier F, Bock J, Klebl F, Strauch U, et al. Analysis of intestinal haem-oxygenase-1 (HO-1) in clinical and experimental colitis. Clin Exp Immunol 2005;140:547-55.

[131] Nakamichi I, Habtezion A, Zhong B, Contag CH, Butcher EC, Omary MB. Heminactivated macrophages home to the pancreas and protect from acute pancreatitis via heme oxygenase-1 induction. J Clin Invest 2005;115:3007-14. 


\section{FIGURE LEGENDS}

\section{Figure 1: Regulatory role of $\mathrm{HO}-1$ in the inflammatory response of macrophages}

Schematic presentation on how $\mathrm{HO}-1$ and its products $\mathrm{BR}$ and $\mathrm{CO}$ might control the balance of pro- and anti-inflammatory cytokines in macrophages. This balance plays a major role in the activation of macrophages and may thus be critical for the regulation of inflammatory reactions. Abbreviations: $\mathrm{BR}$, bilirubin; $\mathrm{CO}$, carbon monoxide; Fe, ferrous iron; IL, interleukin; LPS, lipopolysaccharide; LTA, lipoteichoic acid; TNF $\alpha$, tumor necrosis factor- $\alpha$.

Figure 2: Regulation of HO-1 gene expression via the redox-dependent TFs Nrf2 and

\section{Bach1}

HO-1 gene expression is regulated via the TFs Nrf2 and Bach1, which have counterregulatory functions. Under basal conditions the transcription repressor Bach1 binds to AREs of the HO-1 promoter. When cellular heme levels are high and in response to stress stimuli, Bach1 is removed from the HO-1 promoter. In addition, stress stimuli cause dissociation of Nrf2 from Keap1, which activates HO-1 gene expression after nuclear translocation via binding to HO-1 AREs. Thus, the interplay between Bach1 and Nrf2 appears to be crucial for the regulation of inducible HO-1 gene expression. Abbreviations: ARE, antioxidant response element; Bach1, BTB and CNC homologue 1; HO-1, heme oxygenase-1; Keap1, Kelch-like ECH-associated protein 1; Nrf2, NF-E2-related factor 2; ROS; reactive oxygen species.

Figure 3: Signaling cascades that target Keap1/Nrf2 and Bach1 to regulate HO-1 gene expression

Schematic presentation of major signaling cascades that are involved in the regulation of HO-1 gene expression via interacting with Nrf2 and Bach1. The MAPK p38 $\alpha$ has been shown to activate, but also to inhibit HO-1 gene expression via the TF Nrf2. GSK3 $\beta$-mediated phosphorylation has been shown to regulate the activity of Nrf2 and Bach1. Abbreviations: ARE, antioxidant response element; Bach1, BTB and CNC homologue 1; ERK, extracellular- 
1 


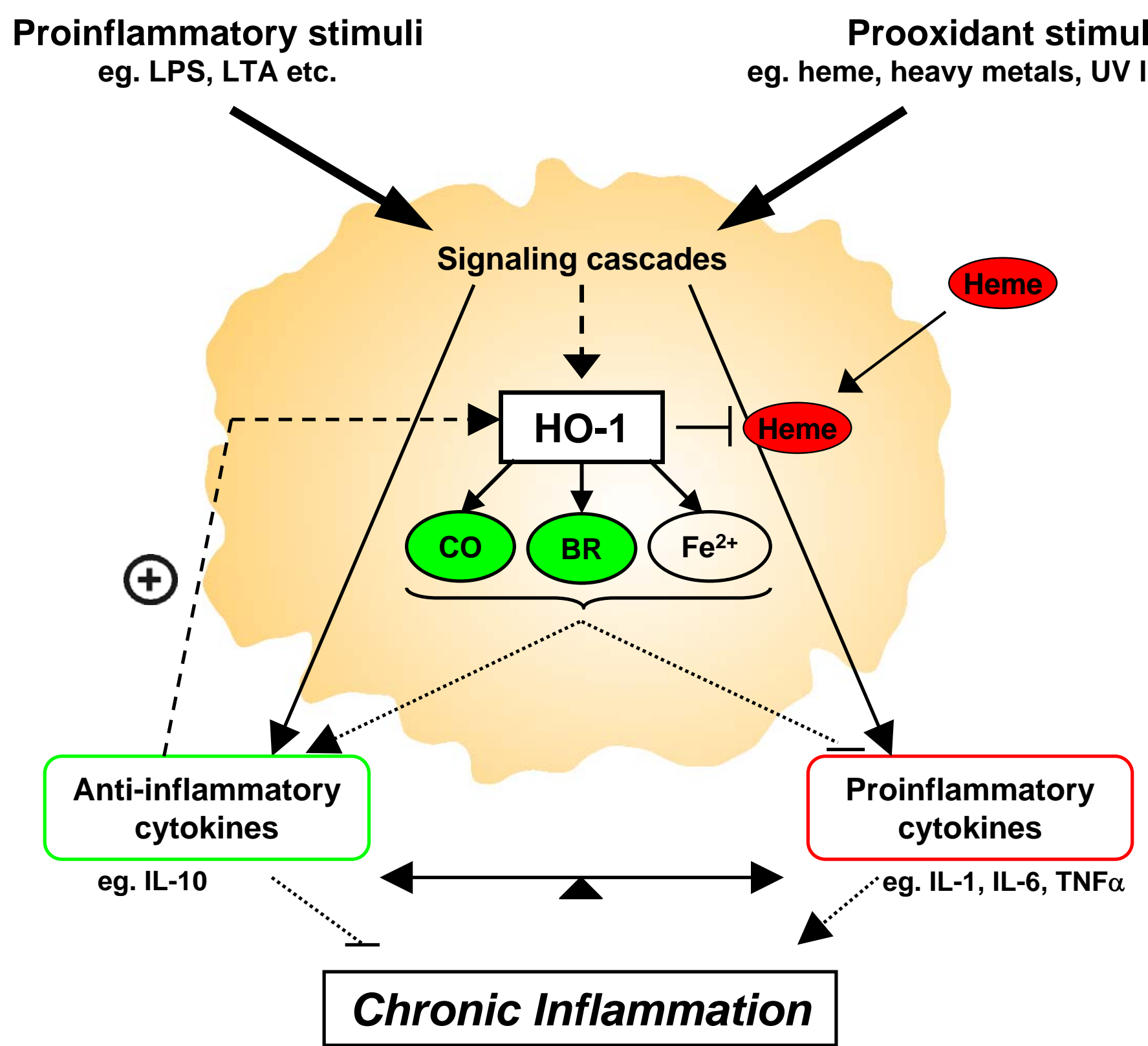


Figure 2
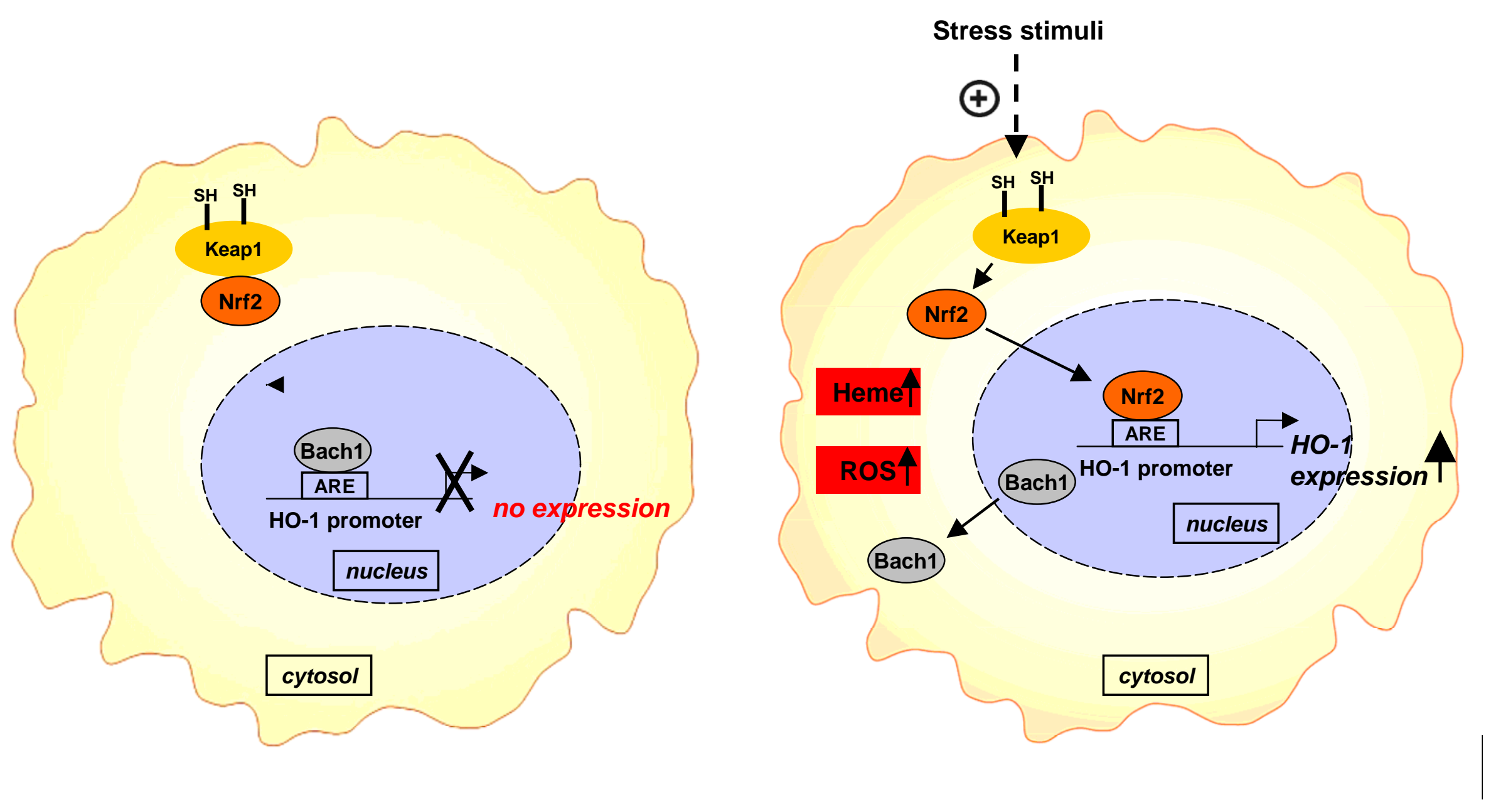

Normal conditions

Prooxidant conditions 
Figure 3

Extra- and intracellular stimuli

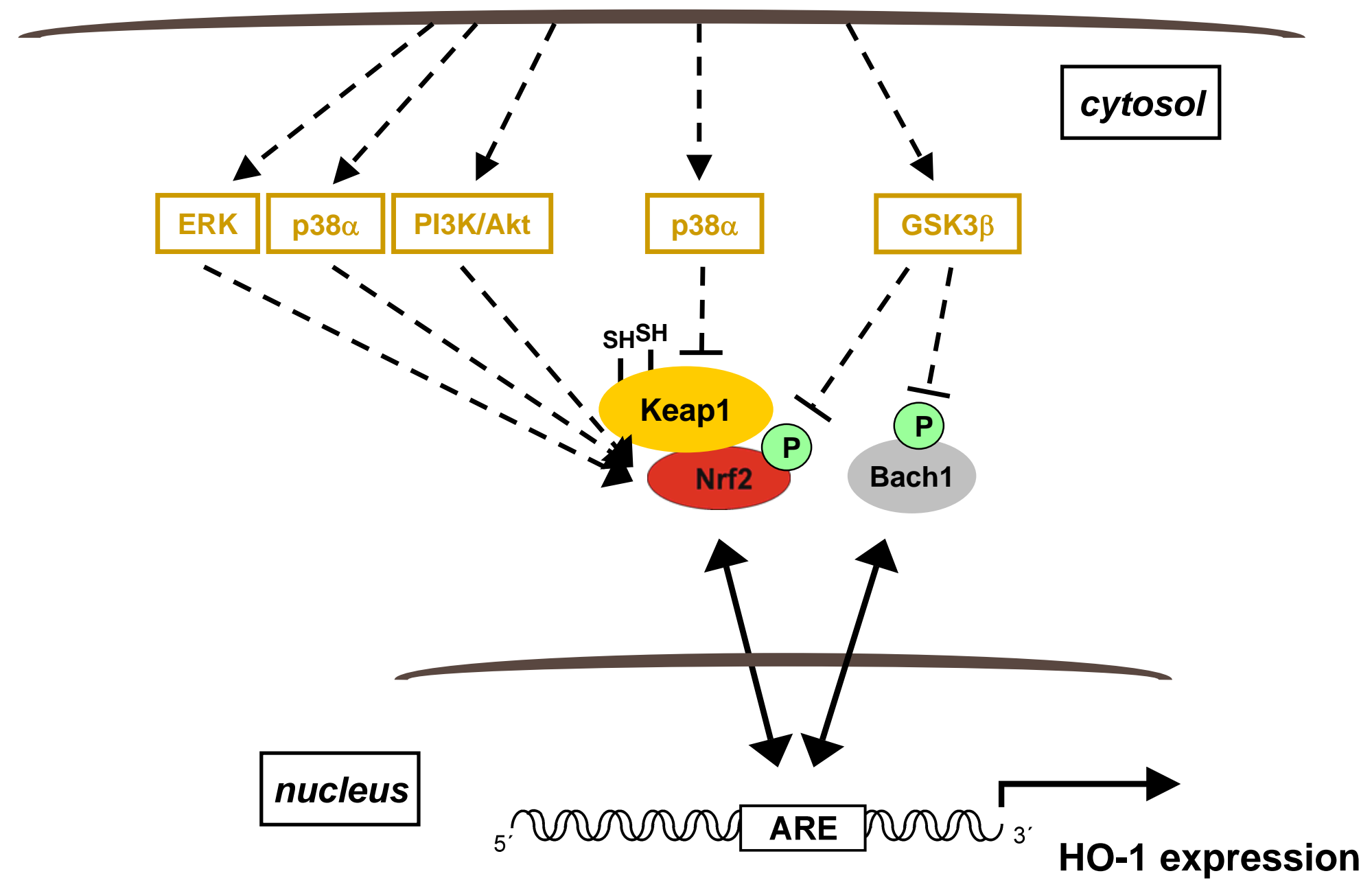


Proinflammatory stimuli eg. LPS, LTA etc.

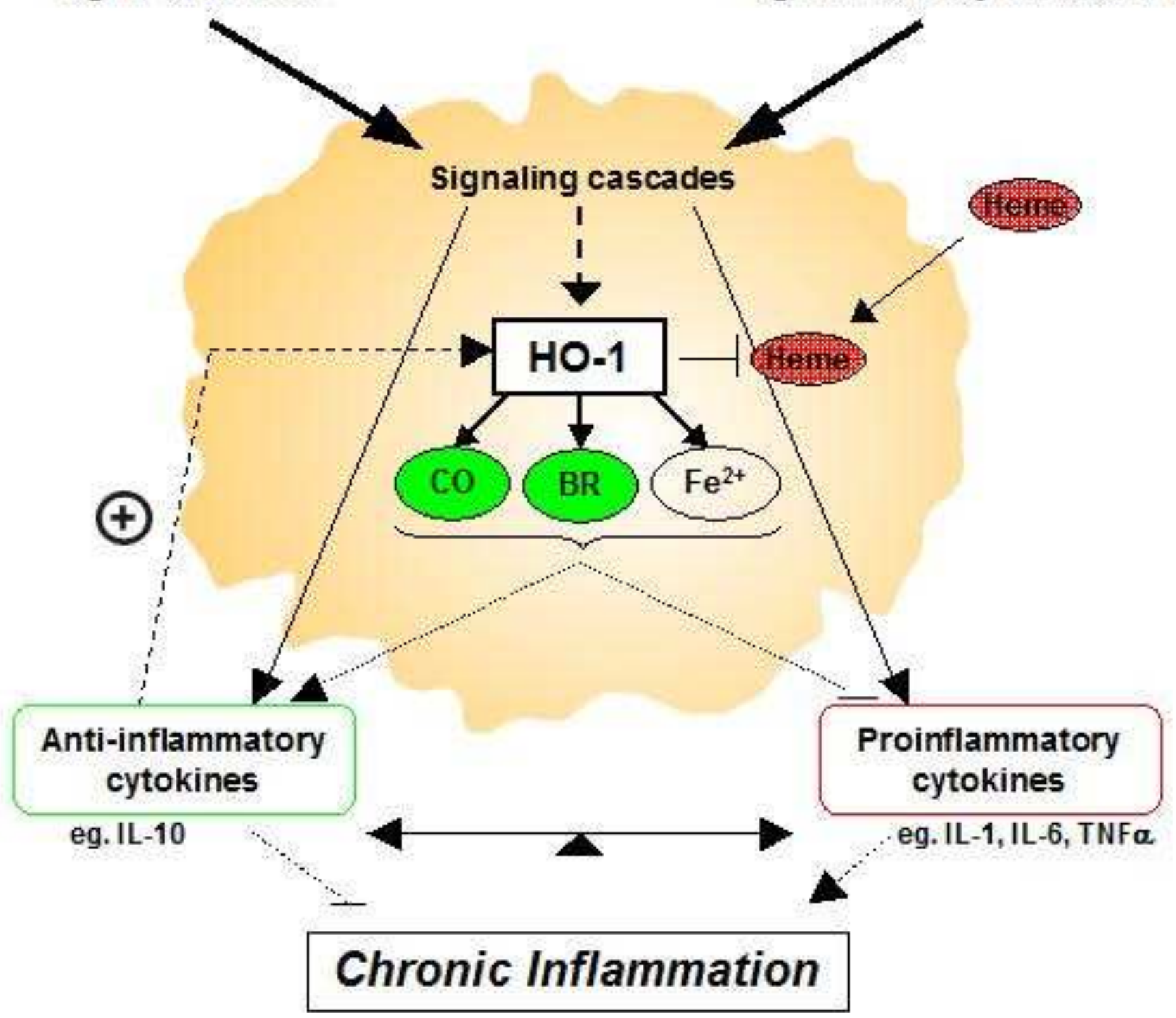

Prooxidant stimuli

eg. heme, heavy metals, UV light etc. 